УДК 81.1

DOI 10.18413/2712-7451-2020-39-3-497-510

\title{
Медицинские инновации и их язык: эмотивнолингвоэкологический подход
}

\author{
${ }^{1)}$ Шаховский В.И., ${ }^{2)}$ Маджаева С.И. \\ 1) Волгоградский государственный социально-педагогический университет, \\ Россия, 400066, г. Волгоград, проспект Ленина, 27 \\ E-mail: shakhovsky2007@yandex.ru \\ 2) Астраханский государственный медицинский университет, \\ Россия, 414000, г. Астрахань, ул. Бабаевская, 121 \\ E-mail: sanya-madzhaeva@yandex.ru
}

\begin{abstract}
Аннотация. Рассмотрена номинация терминопонятий достижений в медицине. Дан анализ способов появления новых терминов. Описаны причины появления новых терминов, их смысл и их влияние на чувствительность экологии реципиента. Установлено влияние прогресса науки на появление новых терминопонятий и их функционирование в коммуникативной практике. Продеманстрровано, как научные достижения в мировой медицине внедряются в новые реабилитационные системы, изменяющие всю систему медицины, делающие её персонифицированной, высокоэффективной и более специфичной. Доказана динамичность совершенствования языка медицины в экологичной научной среде. Проводено кластирование лингвистических изобретений в подъязыке пандемии короновируса по принципу социального и коммуникативного полей.
\end{abstract}

Ключевые слова: терминопонятие, терминообразование, неологизм, медицинский термин, экологический смысл, эмоции пациента, кластирование пандемических лингвем.

Для цитирования: Шаховский В.И., Маджаева С.И. 2020. Медицинские инновации и их язык: эмотивнолингвоэкологический подход. Вопросы журналистики, педагогики, языкознания, 39 (3): 497-510. DOI 10.18413/2712-7451-2020-39-3-497-510

\section{Medical innovations and their language: emotive and linguoecological approach}

\author{
Victor I. Shachovsky ${ }^{1)}$, Sanya I. Madzhaeva ${ }^{2)}$ \\ 1) Volgograd State Social-pedagogical University, \\ 27 Lenin Avenue, Volgograd, 400066, Russia \\ E-mail: shakhovsky2007@yandex.ru \\ 2) Astrakhan State Medical University, \\ 121 Babaevskaya St., Astrakhan, 414000, Russia \\ E-mail: sanya-madzhaeva@yandex.ru
}

\begin{abstract}
The article is devoted to the nomination of the concepts of achievements in medicine. The ways of the appearance of new words are analyzed. The reasons for the emergence of new terms, their meaning, and the influence of new vocabulary on the emotional background of the recipient are described and disclosed. It is established the influence of scientific progress on the emergence of new term concepts and their functioning in communicative practice. It demonstrates how scientific achievements in the world medicine are being implemented in new rehabilitation systems that change the entire system of medicine, making it personalized, highly effective and more specific. The dynamism of improving the language of medicine in an eco-friendly scientific environment is proved. It is suggested the cluster of
\end{abstract}


linguistic reflections in the sublanguage of coronavirus pandemic according to the social and communicative fields.

Key words: terminology, term formation, neologism, medical term, ecological meaning, patient's emotions, clustering of pandemic linguemes.

For citation: Shachovsky V.I., Madzhaeva S.I. 2020. Medical innovations and their language: emotive and linguoecological approach. Issues in Journalism, Education, Linguistics, 39 (3): 497-510 (in Russian). DOI 10.18413/2712-7451-2020-39-3-497-510

\section{Введение}

Развитие медицины обусловлено необходимостью обеспечения гуманитарного благополучия и национальной безопасности страны, охраны здоровья и экологии среды человека и его языка. Среди причин необходимости развития медицины называются:

- увеличение риска возникновения эпидемий (что на сегодняшний день подтверждается COVID-19);

- рост заболеваемости, возвращающиеся и новые инфекции;

- изменение спектра заболеваний;

- меняющаяся демографическая ситуация;

- охрана здоровья и профилактика заболеваний.

Показателем развития общества является появление новых болезней, создание новых препаратов для их лечения, новых технологий, медицинских приборов и лекарств, что выражается в необходимости новых специальностей и специалистов, новых рефлексий всех этих новаций, с одной стороны, медицинским персоналом, с другой - пациентами, а также научными работниками. Такой же процесс затрагивает и язык медицины, который всегда реагирует изобретением новых медицинских номинаций (научных и обиходных), т.е. терминов, отражающие научные инновации на лексическом и синтаксическом уровнях. Новые возможности лечения (пересадка органов, криомедицина, телемедицина, генные технологии и др.) позволяют лечить на более высоком уровне. А совмещение научных достижений и правильное использование, понимание терминопонятий является главным условием в лечении. А так как язык существует лишь в неразрывной связи с мышлением, принцип образования новых терминов действует и на язык «как систему знаков, служащую для хранения, переработки и передачи информации» [Керт, 1967, с. 31]. Изменения в медицине приводят к модификациям в языковой картине мира, функционированию языковых структур. Об этом свидетельствует появление неологизмов, через изучение которых можно увидеть и развитие самой медицины, и трансформацию языковой картины мира медицины. Анализ терминов в соответствии с когнитивно-дискурсивной парадигмой позволяет говорить о роли последних как средства хранения и передачи знаний, а также коммуникации в определённой профессиональной сфере [Сатретдинова, Пенская, 2019].

В систему языка медицины включается большое количество терминов, относящихся уже не только к самому объекту и предмету медицины - человеку и его болезням, но и к методам диагностики и лечения. Медицинский термин, являясь носителем специальной медицинской информации, необходимой для оптимизации познавательной деятельности медиков, обозначает явления, процессы коммуникативно и когнитивно значимые в медицинском пространстве, динамику развития медицины. В процессе этого развития слово может получить специальное значение (нанотехнология, нанобактерия, наноматериал и др.), детерминологизироваться (инъекция, эпидемия, инфекция и др.), возвратиться из прошлого: из архаизмов в историзмы, и наоборот (земский доктор, нулевой пациент и др.). Нередко используются уже известные обиходные слова в терминологических мета- 
форических номинациях - башенный череп, меловой язык, амбарная болезнь и др. Это обусловлено тем, что медицинский термин - «элемент системы, возникающий в результате прогресса медицины; в своем развитии он выступает свидетельством истории существования человека» [Маджаева, 2015, с. 116].

Термин, как инструмент познания, обогащает научные факты, умножает новые знания и передает их горизонтально (современникам) и вертикально (последующим поколениям). Именно так язык осуществляет внутрипоколенные и межпоколенные когнитивные связи.

\section{Основные тенденции развития медицины в наши дни}

Нынешний век уже называют веком нанотехнологий, пришедших на смену компьютерам и телекоммуникациям. Он характеризуется бурным развитием генно-инженерных, био-когнитивных и цифровых технологий, что влияет и на дальнейшее развитие медицины. Примером является появление тканевых и иммунобиологических технологий в медицине, адресная доставка лекарств, в т.ч. онлайн, которые способны в скором времени перевернуть представления о способах, методологии и методах лечения опасных заболеваний, в первую очередь, онкологических и инфекционных. Развитие молекулярной медицины, геномных, метаболомных, протеомных, информационных технологий и т.д. позволяет анализировать большие объемы данных. Кроме того, они создают базис для новых методов лечения заболеваний; обнаружения молекулярных маркѐров заболеваний. Изменения в медицине свидетельствуют о внедрении новых реабилитационных систем (киберсистемы, нейрокомпьютерные интерфейсы), модифицирующих всю систему медицины, делая ее персонифицированной, эффективной и высокоспецифичной.

Следующей тенденцией развития медицины можно назвать интеграцию смежных наук, развитие междисциплинарных исследований и трансляционной медицины. Все чаще встречаются такие понятия, как цифровизащия медищины, ицирровой конилагерь, биохакинг $u$ дp. Уже существуют цифровые приложения в телефонах, которые информируют человека о пульсе, давлении, частоте сердечных сокращений и т.д. Развитие науки, человеческой мысли, открытия, изобретения - причины появления новых терминов.

\section{Причины и смыслы появления новых медицинских терминов}

Медицина нашего времени становится все более технологичной. Она использует технологии искусственного медицинского мониторинга, телемедицину, телефонные приложения, цифровые способы хранения истории болезней, ставшие нашей повседневной реальностью. Новые термины блокчейн, искусственный интеллект в медицине, одежда с функиией медицинского мониторинга, пульсоксиметр, телепсихиатрия, ксенотрансплантациия, обезболивающие гаджеты, ичифровые лекарства, аптамеры, гаджеты, создающие виртуальную реальность для инвалидов, уже становятся понятными для врачей и пациентов. К новым технологиям в области медицины можно отнести и создание искусственного глаза ArgusII, названного в честь греческого мифологического героя, - Всевидящий, многоглазый великан. Существует и другое его название - Second Sight Medical Product; для кардиостимуляторов появились новые названия, точнее аббревиатуры - ЭКС, ИВР - водитель ритма. У них имеются коды согласно их принадлежности к лечению, например, $A$ VI-A - указывает на стимулируемую камеру сердца - предсердие, -V - желудочек, -D - на лечение и того и другого. Номинация данных понятий связана с тем, что себе представил человек, как он понял и воспринял, следовательно, в появлении и функционировании термина большую роль играют психические процессы создания: представление, ощущение, восприятие. 
На технологичность медицины указывает применение роботов, которые проводят лазерную, лучевую, вакуумную, электро- и термотерапию и т.д. Их можно разделить на роботов-хирургов, роботов-помощников, роботов протезирования. Приведем некоторые номинации.

1. Робот-ассистент - с помощью него проводят биопсию, эндоскопию, лазерное рассечение кости, вводят транспедикулярный винт.

2. Диагностический робот - High articulated intelligent Leg, используется для проведения ортопедических анализов, создания биомеханической модели колена.

3. Терапевтический робот или лучевой необходим для смягчения движения опухоли, вследствие адаптации к дыхательным движениям больного. Следовательно, уменьшается воздействие радиации.

4. Робот Cyber Knife применяется при лучевой терапии опухолей.

5. Робот Fanuc ускоряет пакетирование медикаментов на фармацевтических фабриках.

6. Робот, имеющий встроенное компьютерное зрение, многосуставный манипулятор распознает и сортирует предметы, перемещает их. Его используют в уходе за больными. Не имеет точного названия.

7. Антибактериальный наноробот. Его функция - удалить бактерии из крови.

Использование роботов позволит проводить лечение на качественно другом уровне, облегчить труд медиков, сделать его эффективнее и, следовательно, увеличить рентабельность медицинских учреждений. Возможно, применение роботов уменьшит ошибки специалистов, сократит время восстановления и пребывания в стационаре, повысит качество жизни пациента. Тем не менее, их использование может отрицательно воздействовать на психоэмоциональное состояние пациента, и, следовательно, на его личностную экологию. Ведь предназначение роботов - заменить medicus, а это не всегда может быть удачным, так как человек - более тонко-чувствительная натура.

Каждый новый термин имеет свой референт и свой смысл. Каждый новый термин является эмоциогенным как для пациента, так и для специалиста, которому надо привыкнуть к новому термину. Например, проведя опрос среди 23 испытуемых, было выявлено, что слово протез негативно воздействует на всех респондентов, а бионическая рука - нейтрально, не оказывает никакого эмоционального воздействия, как и слово робот. Неизвестный термин бионическая рука вызвал интерес и эмоцию, так как он непонятен. Это подтверждает мысль о взаимосвязи языка и жизни, а «эмоциональная энергия слова, воздействующая на сознание и волю человека, отражается на его физиологии» [Ионова, 2013, с. 10].

Объясним смыслы некоторых новых терминов. Лексема пластырь известна как повседневное слово. Сегодня данный термин функционирует в новом аспекте: у него иной смысл, иные функции. Краткий толковый словарь медицинских терминов дает ему следующее определение: «Пластырь - тонкое полотно или полимерная пленка с односторонним липким покрытием. Используется для закрепления повязок, сближения краев ран» [Радзевич и др., 2004, с. 181]. В современной медицине функционирует такое знание, как пластыри собирают и передают информацию о состоянии здоровья человека, показателях его физической активности. С его помощью ведется мониторинг сердечной деятельности человека, непрерывная электрокардиография амбулаторных пациентов, мониторинг дыхания, уровня глюкозы в крови; отслеживание роста факторов стресса; мониторинг эпилепсии. Такое применение - новое достижение медицины вызывает у пациентов положительные эмоции, удивление и радость.

Использование органов животных для пересадки человеку привело к появлению термина ксенотрансплантащия. 
Для передачи конфиденциальных данных применяется уже знакомый технический термин - блокчейн. Он функционирует в медицине благодаря своей анонимности, децентрализации и криптографическому шифрованию.

Все чаще стал применяться термин биоматериальы, означающий материалы, которые используются для «создания имплантов и эндопротезов, компонентов биологически активных и лекарственных препаратов; носителей, предназначенных для использования в биоинженерных методах. Это препараты, функционирующие в контакте и взаимодействии с живыми тканями, органами...» [Штильман, 2016, с. 4]. Подчеркнем, что в сознании обывателя данный термин ассоциируется с человеческими органами живых людей, которые взяты для «ремонта» взрослых людей и детей. Часто для этого врачи идут на преступление. Поэтому термин биоматериальл неэкологичен, так как воздействует на психику homosapiens негативно.

Продолжим иллюстрации: биохакинг выводит человеческий организм на новый качественный уровень, улучшив самочувствие пациента и наладив процессы его жизнедеятельности. Прибор пульсоксиметр считывает степень насыщенности артериальной крови кислородом, оценивает уровень гипоксии при беременности, у недоношенных детей и детей младшего возраста, при анемии, большой кровопотере, при транспортировке больных, при болезни легких и анестезии во время операций. Новые термины с прилагательным перинатальный (перинатальный центр, перинатальная медицина, перинатальная клиника) не обозначают специфический роддом. Этот термин обозначает соединение действий по оказанию медицинской помощи в дородовый, послеродовый периоды и уход за матерью и ребенком.

Термин телепсихиатрия был введен в терминологию американским психиатром Томасом Дуайером в 1973 году, но широкое его употребление связано с распространением интернет-коммуникаций. Российские ученые разработали цифровые лекарственные средства для борьбы с раковыми клетками. В их основе лежат специальные молекулярные конструкции (аптамеры), с помощью которых определяются циркулирующие опухолевые клетки в крови. Роботизированная технология Genie Connect используется для помощи и эмоционального поддержания одиноких людей. Измерение коркового беспорядка (СДМ) новый уровень детализации МР-сканирования головного мозга пациента. Все вышеназванные термины экологичны, так как они положительно воздействуют на сознание реципиента и образуют позитивно заряженную картину мира пациента.

Актором сегодняшнего дня является новая коронавирусная инфекция - COVID-19. Международный комитет по таксономии вирусов 11.02. 2020 присвоил официальное название возбудителю инфекции SARS-Cov-2 [Минздрав России, 2020]. На примере термина коронавирус верифицируется суждение, что термин динамичен, если не изменяется его оболочка, изменяется его сущность. В начале появления заболевания в новостях применялся термин коронавирус, но это не было заболеванием. Коронавирус - причина заболевания, притом, многих заболеваний. Это семейство вирусов, включающее на январь 2020 года 40 видов РНК-содержамих вирусов, объединённых в два подсемейства, которые поражают человека и животных. Название связано со строением вируса, шиповидные отростки которого напоминают солнечную корону. Назначение «короны» у коронавирусов связано с их специффическим механизмом проникновения через мембрану клетки путём имитации «фальшивыми молекулами» молекул, на которые реагируют трансмембранные рецепторы клеток. После того как рецептор захватывает фальшивую молекулу c «короны», он продавливается вирусом в клетку, и за ним РНК вируса входит в клетку [Кронавирусы. Википедия]. Затем появился термин коронавирусная инфекция, впослед- 
ствии - новая коронавирусная инфекиия. (Также использовались разные варианты аббревиатур данного понятия - 2019-nCoV, COVID-2019, nCOVID-19, кор(корона)вирус и т.д.).

Большое количество номинаций данного заболевания свидетельствует о непонимании или о пока еще неявном знании, течении и последствий инфекции. Поэтому в газетах появились такие слова и словосочетания, связанные с заболеванием, - китайская пневмония (по месту локализации), смертельный вирус (угроза), коронованньий убийца (функция), идеальное оружие. Смысл термина коронавирус изменился, так как изменились симптомы и признаки заболевания. Это подтверждает суждение Ф. Риггза, считавшего отношение понятий к терминам и слов к понятиям как «одно ко многим», что каждое понятие может быть обозначено многими терминами, и каждое слово может быть связано со многими понятиями [цит. по Буяновой, 2012, с. 70]. Поэтому термин коронавирус можно интерпретировать как необходимость детализации свойств, явлений, признаков, требующих адекватной номинации.

Конкретное понятие вирус (от лат. Virus - яd) - субмикроскопический инфекционный агент, возбудитель инфекционных (вирусных) болезней человека, животных, растений [Радзевич, 2004, с. 16], является как бы основным фреймом, так как вирус является возбудителем заболевания. Это понятие актуализируется вышеназванными терминосочетаниями, аббревиатурами. В любом случае термин коронавирус является, бесспорно, неэкологичным, так как вызывает неприятные ассоциации и переживания. Новый термин создает и новый вид знания. Коронавирус (новый тип вирусов) - новая коронавирусная инфекция (изучение симптомов, признаков, лечение, профилактика) - COVID-19 - изобретение (разработка) новой вакциньы.

Вышеприведенный текст демонстрирует дескриптивную функцию языка: описаны некоторые параметры и происхождение данного термина. Но на примере данного заболевания можно продемонстрировать роль лингвистики в науке: именно благодаря ей она называет заболевания, с развитием знаний о нем она варьирует эти названия от научного до бытового, фиксирует все происходящее в связи с этим заболеванием: названия лекарств, медицинской аппаратуры, медицинских процедур, их методов и приемов, различных этапов заболевания и результатов его лечения, различных переживаний, связанных с ним, как врачей, так и пациентов, и мн. др. Самая главная функция лингвистики - информационная, как горизонтальная (внутрипоколенная), так и вертикальная (межпоколенная) трансляция информации о ходе протекания болезни и методах ее лечения.

Приведем пример роли лингвистики, построив коммуникативное поле пандемии «Короновирус». Конечно, данное поле не может быть полным, поскольку оно схематично и субъективно, т.к. построено на промежуточных знаниях авторов данной статьи, полученных и прочитанных в СМИ и Интернете: изготовление масок (одноразовых и многоразовых), тестирование, чипирование, масочный и перчаточный режим, вакцинация, административные шттафы, селфи по электронному контролю за местонахождением самоизолированного пациента, самоизоляичи, удалёнка (удаленная работа, обучение, преподавание), QR-контроль, открытие новых производств по изготовлению масок и зашитных костюмов для медииинского персонала, доставка аппаратов и масок из-за рубежа, динамика статистики заболевших, выздоровевших и умерших, пик пандемии, плато, социиальная дистанция, доставка волонтерами продуктов и лекарств пожильм людям, прокороноваться, встреча с короновирусом, короно(кор)вир, протесты медиков, не получивших доплату за работу с вирусныли больными, недоплата медикам, возбуждение уголовных дел против администрации больнии, обращение медиков к президенту о трудностях в работе лечебных учреждений, самовозгорание аппаратов ИВЛ и пожары в больнииах, гибель пациентов от пожаров, оптимизаџия медицины, истерия с пандемиейи др. 
Вышеприведенный далеко не полный список лингвем коммуникативного поля пандемии «короновирус» убедительно демонстрирует роль языка в формировании специфического вокабуляра, функционирующего в глобальном социуме и отражающего события, процессы, связанные с ним, акторы, объекты, действия, результаты (последствия). Эти и многие другие языковые знаки, изобретенные в коммуникативном пространстве данного события, навсегда останутся в форме лингвистических коконов с очень болезненным для человечества содержанием. Многие из них нейтральны, многие оценочны, экспрессивны и даже эмотивны, особенно в связи с определенными ассоциациями у членов глобального социума. Есть и инвективные в обиходном общении, которые здесь по экологическим соображениям не приводятся.

Не все термины прошлого века стали хорошо известными; они функционируют только в определенном подъязыке медицины, в отличие, например, от термина коронавиpyc. Приведем пример: медицинский термин салонное слабоумие подразумевает низкий интеллектуальный уровень, маскируемый внешне кажущейся хорошей, но построенной на шаблонах речью, усвоенными в процессе воспитания манерами, изысканной одеждой, известной социальной установкой и духовными претензиями, проявляется, главным образом, в заученной фразеологии при скрытой недостаточности критик суждений. Немецкий ученый Блейлер назвал этот синдром die Unklaren - неясные. В статьях используются такие его вариации, как конституциональная глупость и ункларены.

Таким образом, смысл появления новых медицинских терминов заключается в предоставлении врачам, пациентам, научному сообществу достоверной, объективной информации о каком-либо медицинском феномене или процессе.

\section{Способы образования новых медицинских терминов}

Терминосистема медицины увеличивается количественно, в частности, за счет открытия и описания новых нозологических единиц. В связи с этим появляются специфические терминологические подсистемы, обслуживающие отдельные медицинские дисциплины и их подъязыки, например, биомедицина, криомедицина и т.д. Необходимость номинировать новые болезни, явления, являющиеся результатом развития медицины, способствует появлению новых медицинских терминов.

Новые термины можно классифицировать следующим образом:

1. Заимствования из греческого и латинского языков: телемедицина, нозокинетика, фармакогеномика, наномедицина и др.

2. Заимствования из английского, французского, немецкого, испанского, арабского и других языков, применяемые в профессиональном медицинском языке: стентирование, шунтирование, геронтоль, блокчейн, РНК-терапия и др.

3. Заимствования - транскрипция иностранных слов: антиэйджсиг и др. Так называемые европеизмы, производные от английских слов.

4. Псевдонаучные терминологические сочетания, не несущие смысловой нагрузки: гестаиидный возраст, ичифровая медицина, ичифровые лекарства и др.

5. Авторские термины: напечатанные кости, агропедоценоз и др.

6. Межнаучные (междисциплинарные или «всепригодные») термины: мониторинг, скрининг и др.

7. Термины-словосочетания, составляющие лингвистические измышления авторов: коктейль из микроорганизмов, «исследование популяџии подростков», китайская пневмония и др. 
Новые медицинские термины образуются:

1) путем соединения двух (а иногда и более) слов без учета их морфологической структуры и основанной большей частью на созвучии или благозвучии соединяемых частей, например, нанолатимизированный композит, биопраймер, вестерн-блоттинг, бэбибокс и др.;

2) толкования: автобуса симптом - неспособность больных самостоятельно поднять ногу на ступеньку, сопровождающаяся неспособностью самостоятельно встать, сесть; амбарная болезнь - один из видов эндогенного аллергического альвеолита;

3) аббревиации - D4W - Dental 4Windows - программа для стоматологических клиник, COVID-19 - новая коронавирусная инфекция и др;

4) калькирования - hostcell - клетка хозяин, тетоrycell - клетка памяти, Visor for prehospital hemorrhage - забрало для диагностики догоспитального инсульта, партисипативная медицина и др.;

5) метафоризации - немая почка, водитель ритма, осиной талии симптом, кибернож, датчики мозга, золотые нити и др. Метафоризация объясняется тем, что метафора коммуникативно более эффективна, так как она ориентирована на широкий круг реципиентов, а антропологический подход позволяет метафорам функционировать в языке. По мнению В.М. Лейчика, «метафоризация - центральный процесс среди многочисленных процессов формирования терминов» [Лейчик, 2010, с. 305]. Это обусловлено тем, что новая языковая конструкция приобретает осмысленный характер, включаясь в уже привычные контексты мыслительно-языковой деятельности [Маджаева, 2011]. Олицетворение это определенное мышление, наделение неодушевленных предметов человеческими способностями. Например, кардиостимулятор, дословно можно перевести стимуляции сердuза. У данного термина есть синоним pacemaker (пейсмейкер - этимология - расе - скорость, ритм итаker - тот, кто что-то делает, творит) - создатель ритма. (Не wеars a pacemaker to help maintain a regular beating of his heart. Он носит кардиостимулятор, чтобы помочь поддерживать регулярное биение своего сердиа). В России используется термин кардиостимулятор, в то время как в странах Европы и США функционирует pacemaker. На наш взгляд, термин кардиостимулятор содержит в себе образ-оценку и передает заключенный в нем позитивный смысл, «не сулит ничего плохого», а только стимулирует деятельность сердца, а значит - он экологичен. Функционирование метафор в языке медицины обусловлено быстрым развитием медицины, специалисты не успевают создать новые номинациии, используют самые обычные распространенные слова во вторичном, метафорическом значении: жировое тело щееки, привычный выкидыш, артериальные озера и др.

Надо отметить тот факт, что развитие медицины, ее терминологии приводит к возникновению новой лексики, словосочетаний, имеющих в своем составе медицинские термины. Например, обиженный желудок, конфетный градусник, финансовый тромб, финансовая инфекиия, наркотик сепаратизма, агрессивная хирургия, метастазы войны и др. Данные метафоры и олицетворения помогают постичь основы мышления человека, процессы создания нового видения мира и его нового отражения в языке медицины, то есть в языковой картине медицинского мира. Они экспрессивно-оценочны, так как в основном используются в языке СМИ, художественной литературе и облегчают обиходное общение.

Нельзя не согласиться с суждением Е.С Кубряковой [1997], что терминообразование представляет собой сложно-структурированный когнитивно-креативный процесс, включающий передачу и получение закодированной языковыми средствами информации. Важную роль играет условие его осуществления, ситуация, включающая экологичность среды. Терминообразование связанно со значимостью заболевания, инструмента, специ- 
альности, и потому можно говорить об эмотивно-когнитивном процессе, связанном с переживаниями того, кто даёт имя, и кто его использует или слышит. Появление новых профессий в медицине верифицирует данное суждение. Например, архитектор медицинского оборудования. Слово архитектор не относится к сфере медицины. Тем не менее, коммерциализация, применение высокотехнологичного оборудования приводит к востребованности специалиста, сочетающего умение конструирования и понимания особенностей организма человека. Новые профессии в области медицины: IT-генетик, занимающийся программированием генома под заданные параметры, молекулярный диетолог, разработчик киберпротезов и имплантов - еще не устоявшиеся терминопонятия, в отличие от подобных: генная инженерия, генное редактирование, редактирование генома и т.n. Думаем, они трансформируются в процессе функционирования в более емкие и точные, так как «образование новых слов, появление новых значений обусловлено неустанной креативной работой человеческого сознания, бесконечным познавательным процессом, детерминированным предметно-практической и интеллектуальной деятельностью человека [Касьянова, 2009]. Этот процесс продолжается. И он бесконечен.

\section{Эмоциогенность медицинских неологизмов}

Меняющиеся условия показывают, что положительное воздействие на язык стимулирует как его развитие и обогащение, так и негативное влияние [Эмотивная лингвоэкология, 2013]. Мы уже отмечали, что содержание медицинского термина может быть эмоциогенным. Это обусловлено тем, что медицинские понятия связаны со здоровьем и жизнью человека. Они становятся личностно значимыми и указывают на сферу профессиональных рисков (см. выше о коронавирусе) [Маджаева, 2015а]. Некоторые термины вызывают эмоции, так как они создаются человеком, отражают движение человеческой мысли и чувствований. Современные термины образуют особое экологическое пространство, которое может быть как экологичным, так и неэкологичным для человека, способствовать его развитию или негативно влиять на его жизнедеятельность, а иногда и на саму человеческую природу [Ионова, Шаховский, 2012].

На нынешний момент эмоциогенным является термин коронавирус (COVD-19). СМИ, рекомендации ВОЗ, которые постоянно меняются, производят эмоциональный эффект, давление на реципиента. В связи с тем, что медицина не знает способов его лечения, данный термин негативен. Поэтому на сегодняшний день такие словосочетания, как сидим дома, полная изоляция, разработка вакцины, отсутствие масок, чрезвычайная ситуация, пенсионеры от 65 лет и т.д. являются характеристикой данного заболевания и определяют оценочную семантику данного термина, так как заболевание представляет собой повышенный риск смерти. Для передачи эмоции и указания на опасность заболевания используются слова и словосочетания - изолящия, самоизолящия; нулевой паџиент; отмена спортивных соревнований, культурных развлечений; карантин, комендантский час. Даже положительно-эмоциональные словосочетания дистанционное обучение, дистанционный туризм стали отрицательно воздействовать на сознание пациента. Искаженная медицинская информация способствует проявлению таких эмоций, как опасность, паника, а следовательно, появляется эмоция страх.

Особенностью появления и функционирования данного понятия является отражение ситуации в мире и, как следствие, вокруг него формируется социальное поле, которое отображает его соответствующими номинациями (вербемами). Фактически, это структурированное поле с ядром, периферией, маргиналией, которое находит свое место в пазле медицинской картины мира. Она предстаёт тоже в виде поля, но очень большого, состоящего из микрополей, такого как «коронавирус». Причиной эмоциогенности данного забо- 
левания является его неизученность и быстрая распространяемость. Данное заболевание неизвестно, вокруг него много загадок, что влияет и на эмоциональное поле человека, и поэтому термин COVID-19 «фиксирует это переживание как видовой эмоциональный опыт в языковых знаках-эмотивах» [Шаховский, 2019, с. 36].

Новые медицинские термины получают эмоциональное осмысление по причине появления нового типа знания, его неизвестности. Заболевание коронавирус отрицательно воздействует на сознание человека, так как заболевание образует (формирует) острую психологическую ситуацию. В связи с этим появляются слова с эмоциональным осмыслением (эмотивы) как реакция на понятие. Это обусловлено тем, что «любая мысль зарождается в человеческом сознании первоначально в виде эмоционального образа» [Шаховский, 2019, с. 36]. Эти слова придумываются журналистами как субъектами инфодемии, которые как бы заряжают слово отрицательной энергетикой (рукотворный вирус). То есть термин существует не сам по себе, он создает различные терминополя, так как не может жить сам по себе.

В процессе исследования эмотивы, характеризующие коронавирус и функционирующие в СМИ, были распределены на три области - ядерную, приядерную, маргинальную.

1. Ядерная область:

A) коронавирус, COVID-19, вирус, геном, пневмония, эпидемия, пандемия, катастрофа всемирного масштаба, тест на COVID-19 и др.;

Б) ИВЛ, инвазивная хирургия, инфицирование, заболевание, тестирование, лечение, стройка инфекционных больниц, перепрофилирование больниц (палат); витальньй исход; инфекция, распространение вируса; волонтер, новье симптомы и др.;

В) самоизолящия, сочиальная дистанциия (изолящия), сидим дома, ицировой пропуск, дистанционное обучение, карантин, ЧС; медицинские маски, антисептик, перчатки, средства самозашиты в условиях коронавируса, патриотизм врачей и др.

2. Приядерная область: санитарная катастрофа; саниторайзер (антисептик), вторая волна эпидемии, рукотворный вирус, химическая пневмония, циифровое рабство, чип, плато, пик, штраф, вторая волна эпидемии, «масок нет»; «щейте бахиль сами», мировая афера, депрессия от самоизоляции (иифровой зависимости); разобщение людей; агрессия по отношению к инфицированным со стороны соседей и др.

3. Маргинальная область: математическая модель (статистики); инфодемия; китайская пневмония, выходные дни, военная вакцинация, либеральный вирус, Онищенко: «сидят в тюрьмах», игрище в статистику (инфищирование, заболевание, вылечивание, смертность), экзоскелет (Волгоград), домашнее СИЗО, корантикуль, ковидиь, «самоизолящия остается дома» и др.

Приядерная и маргинальная области подтверждают суждение В.И. Шаховского о том, что «шлюзы этических норм опущены, шлагбаумы риторической речи подняты - бурлят, кипят эмоции во всех дискурсах, и не только медийных» [Шаховский, 2018, с. 287].

В первой области выделены слова - символы эмоций, функционирующие для описания заболевания COVID-19. Внутри данной области можно выделить темы: «Название болезни», «Лечение», «Профилактика». Эмоционально-медийная сфера преобладает в теме «Профилактика». Здесь же функционируют и синонимы: изолящия = самоизоляция =

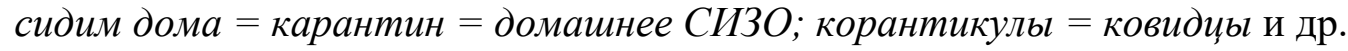

Наиболее частотные эмоции, провоцируемые ядерными номенами, негативные. В изучаемой области функционируют медицинские термины, которые не были столь распространенными в широких кругах, например, ИВЛ- искусственная вентилящия легких. На этом этапе данное понятие известно (что это такое, его функции, где его производят и даже, сколько) в связи со значимостью его применения при коронавирусе. 
В приядерной области повторяются темы первой области, но слова данной области менее активны в коммуникативной деятельности, в то время как слова маргинальной области, несмотря на их новизну, не активны до поры до времени.

Термин ичифровой пропуск также является результатом работы человеческого мозга, достижения, но уже другой области науки (цифровой логистики). Причиной известности данного понятия можно назвать возникновение и распространение заболевания. Таким образом, можно отметить тот факт, что терминополе медицинской картины мира находится в постоянном развитии, оно «дышит» вместе «с духом народа, обновляется и может быть представлено в определенном отрезке времени лишь фрагментарно» (см. выше коммуникативное поле лингвем пандемии «Короновирус») [Шаховский, 2019, с. 40].

Анализ медицинских заболеваний показал, что болезни отступают, а термин со временем теряет свою эмоциогенность. Так произошло с Эболой, атипичной пневмонией, птичьим гриппом. Это обусловлено изменением медицинской картины мира, когнитивной базой индивида. Человек получает точную информацию о болезни, лечении, лекарственных средствах, мерах по профилактике. Следовательно, он уверен в излечении заболевания, и эта «уверенность положительно влияет на эмоциональный фон восприятия слова и категориальные ситуации его употребления» [Маджаева, 2012, с. 102].

Новые медицинские термины вызывают эмоции и страха, и неуверенности, и паники. Их смысл не понятен больному, следовательно, новый термин личностно ориентирован и может отражать эмоциональное отношение к проблемам здоровья.

\section{Заключение}

Прогресс двигается человеком, и понятия, номинируемые им, связаны с его мышлением, в том числе и эмоциональным. Новые термины указывают на появление новых типов знаний. Примеры таких новых знаний приведены в статье, а многие новые знания остались за ее пределами. Но все они доказывают справедливость нашего тезиса: медицинские инновации картируются языком и запускаются в вербалику. На сегодняшний день в российской медицине функционируют заимствованные термины, которые должны стать интернациональными. Считаем, что наряду с ними должна функционировать и исконная лексика. Наличие синонимов позволит подтвердить, какой из этих терминов укоренится в терминологии языка медицины.

Иногда новый медицинский термин не экологичен: новый медицинский термин содержит настороженность, страх.

Лексико-синтаксические инновации в языке современной медицины создаются не только мышлением и сознанием ученых, но и их эмоциями, соответствующими определенной коммуникативно-экологической среде. Язык медицины включает в свою терминологию и эмоциональные обозначения, основанные на метафоризации и олицетворении, выполняющие когнитивно-эмотивную функцию.

Новые термины могут вызывать как положительные, так и отрицательные эмоции. Причиной их эмоциогенности является страх, вызванный быстрой распространенностью, неизвестностью ее преодоления и лечения этого заболевания. Новые термины могут кластироваться в ядерные, приядерные, маргинальные области, переходить из одной области в другую.

\section{Список источников}

1. Коронавирусы. Википедия. Свободная энциклопедия. URL: https://ru.wikipedia .org/wiki/Коронавирусы (дата обращения: 29.03.2020). 
2. Минздрав России, 2020. Профилактика, диагностика и лечение новой коронавирусной инфекции (COVID-19). Временные методические рекомендации, Москва, 8 апреля 2020 г. Версия 5. M., $121 \mathrm{c}$.

3. Публичный аналитический доклад по научно-технологическому направлению «Биомедицина». Федеральный реестр экспертов научно-технической сферы. URL: https://reestr.extech.ru/docs/analytic/public_reports.php (дата обращения: 23.03. 2020).

4. Радзевич А.Э., Куликов Ю.А., Гостева Е.В. 2004. Краткий толковый словарь медицинских терминов. Под ред. А.Э. Радзевича, Ю.А. Куликова, Е.В. Гостевой. М., МЕДпрессинформ, 368 с.

\section{Список литературы}

1. Буянова Л.Ю. 2012. Термин как единица логоса. Под ред. Л.Ю. Буяновой. М., ФЛИНТА, Наука, 224 с.

2. Ионова С.В., Шаховский В.И. 2012. Человек и его языковая среда: эколингвистический аспект. В кн. Антропология языка. Под ред. С.Р. Омельченко. Вып. 2. М., Флинта, Наука: 137-149.

3. Ионова С.В. 2013. Эмотивная лингвистика: от глубин слова к широте социальных коммуникаций. В кн. Человек в коммуникации: от категоризации эмоций к эмотивной лингвистике. Сборник научных трудов, посвященный 75-летию профессора В.И. Шаховского. Под ред. Н.Н. Панченко. Волгоград, Волгоградское научное издательство: 9-12.

4. Ефремова Л.В. 2018. Неологизмы в современной русской медицинской терминологии. Филологические науки. Вопросы теории и практики, 3 (81): 319-322.

5. Касьянова Л.Ю. 2009. Когнитивно-дискурсивные механизмы неологизации. Под ред. Н.Ф. Алефиренко. Астрахань, Издательский дом «Астраханский университет», 320 с.

6. Керт Г.М. 1967. К вопросу о взаимоотношении языка и мышления. В кн. Язык и мышление. Под ред. Ф.П. Филина. М., Наука: 30-37.

7. Кубрякова Е.С. 1997. Части речи с когнитивной точки зрения. Под ред. Е.С. Кубряковой. М., Ин-т языкознания РАН, 331 с.

8. Лейчик В.М. 2010. Метафоризация как способ образования научных и технических терминов (на материале лексики языка компьютерного дела). В кн. Терминология и знание. Материалы II Международного симпозиума, Москва, 20-21 мая 2010 г. Под ред. С.Д. Шелова. М., Изд. центр «Азбуковник»: 292-306.

9. Маджаева С.И. 2011. Способы номинации в медицинской терминологии. Электронный научный журнал «Мир лингвистики и коммуникации», 1 (22). URL: http://tverlingua.ru (дата обращения: 30.03.2020).

10. Маджаева С.И. 2015. Медицинские термины в динамике. В кн. Язык медицины. Международный межвузовский сборник научных трудов в честь юбилея В.Ф. Новодрановой. Под ред. В.Ф. и др. Вып. 5. Самара, KRYPTENВолга: 113-117.

11. Маджаева С.И. 2015а. К проблеме эмоциогенности медицинского термина. Вестник РУДН. Серия Лингвистика, 1: 94-104.

12. Сатретдинова А.Х., Пенская 3.П. 2019. Медицинские термины в учебнопрофессиональном дискурсе. Журнал фундаментальных и прикладных исследований «Гуманитарные исследования», 3 (71): 56-60.

13. Шаховский В.И. 2008. Лингвистическая теория эмоций. М., Гнозис, 416 с.

14. Шаховский В.И. 2013. Эмотивная лингвоэкология в современном коммуникативном пространстве. Под ред. В.И. Шаховского, Н.Н. Панченко. Волгоград, Изд-во ВГСПУ «Перемена»: 8-23.

15. Шаховский В.И. 2018. Ускоренная коммуникация как потребность современного социума. В кн. Языковое бытие человека и этноса. Материалы XV Березинских чтений, Москва, 25 мая 2018 г. Под ред. В.А. Пищальниковой, Л.Р. Комаловой, Н.Н. Германовой. М., Ин-т научной информации по общественным наукам РАН, 20: 285-293.

16. Шаховский В.И. 2019. Категоризация ЭМОЦИЙ в лексико-семантической системе языка. M., URSS, 206 с. 
17. Штильман М.И. 2016. Биоматериалы - важное направление биомедицинских технологий. Вестник Российского государственного медицинского университета, 5: 4-15.

\section{References}

1. Buyanova L.Yu. 2012. Termin kak edinitsa logosa [The term as a unit of logo]. Ed. L.Yu. Buyanova. M., Publ. FLINT, Nauka, 224 p.

2. Ionova S.V., Shakhovsky V.I. 2012. Chelovek i ego yazykovaya sreda: ekolingvisticheskiy aspekt [Man and his linguistic environment: ecolinguistic aspect]. In: Antropologija jazyka [The anthropology of Language]. Ed. S.R. Omel'chenko. Vyp. 2. M., Publ. Flint, Nauka: 137-149.

3. Ionova S.V. 2013. Emotivnaya lingvistika: ot glubin slova $\mathrm{k}$ shirote sotsial'nykh kommunikatsiy [Emotive linguistics: from the depth of the word to the breadth of social communications]. In: Chelovek v kommunikatsii: ot kategorizatsii emotsiy k emotivnoy lingvistike [The Man in communication: from categorization of emotions to emotive linguistics]. Collection of scientific papers dedicated to the 75th anniversary of Professor V. I. Shakhovsky. Ed. N.N. Panchenko. Volgograd, Publ. Volgogradskoe nauchnoe izdatel'stvo: 9-12.

4. Efremova L.V. 2018. Neologizmy $\mathrm{v}$ sovremennoy russkoy meditsinskoy terminologii [Neologisms in modern Russian medical terminology]. Philology. Theory \& Practice, 3 (81): 319-322.

5. Kasyanova L.Yu. 2009. Kognitivno-diskursivnye mekhanizmy neologizatsii [Cognitivediscursive mechanisms of neologization]. Ed. N.F. Alefirenko. Astrakhan', Publ. Astrakhanskiy universitet, $320 \mathrm{p}$.

6. Kert G.M. 1967. K voprosu o vzaimootnoshenii yazyka i myshleniya [To the question of the relationship between language and thinking]. In: Yazyk i myshlenie [Language and thinking]. Ed. F.P. Filin. M., Publ. Nauka: 30-37.

7. Kubryakova E.S. 1997. Chasti rechi s kognitivnoy tochki zreniya [Parts of speech from a cognitive point of view]. Ed. E.S. Kubryakova. M., Publ. In-t yazykoznaniya RAN, 331 p.

8. Leychik V.M. 2010. Metaforizatsiya kak sposob obrazovaniya nauchnykh i tekhnicheskikh terminov (na materiale leksiki yazyka komp'yuternogo dela) [Metaphorization as a way of forming scientific and technical terms (based on the lexicon of the computer science language)]. In: Terminologiya i znanie [Terminology and knowledge]. Proceedings of the II International Symposium, Moscow, may 20-21, 2010. Ed. S.D. Shelov. M., Publ. Azbukovnik: 292-306.

9. Madzhaeva S.I. 2011. Sposoby nominatsii v meditsinskoy terminologii [Some ways of nomination of medical terminology]. World of Linguistics and Communication, 1 (22). Available at: http://tverlingua.ru (accessed: 30.03.2020).

10. Madzhaeva S.I. 2015. Meditsinskie terminy v dinamike [Medical terms in dynamics]. In: Yazyk meditsiny [Language of medicine]. International Intercollegiate collection of scientific papers in honor of the anniversary of V. F. Novodranova. Eds. V.F. Novodranova. Vyp. 5. Samara, Publ. KRYPTENVolga: 113-117.

11. Madzhaeva S.I. 2015a. K probleme emotsiogennosti meditsinskogo termina [To the problem of emotionality of the medical term]. Russian Yournal of Linguistics, 1: 94-104.

12. Satretdinova A.Kh., Penskaya Z.P. 2019. Meditsinskie terminy v uchebno-professional'nom diskurse [Medical terms in educational and professional discourse]. Journal of fundamental and applied researches «Humanitarian Researches», 3 (71): 56-60.

13. Shakhovskiy V.I. 2008. Lingvisticheskaya teoriya emotsiy [Linguistic theory of emotions]. M., Publ. Gnozis, 416 p.

14. Shakhovskiy V.I. 2013. Emotivnaya lingvoekologiya v sovremennom kommunikativnom prostranstve [Emotive linguoecology in the communicative space]. Eds. V.I. Shakhovskiy, N.N. Panchenko. Volgograd, Publ. Izd-vo VGSPU «Peremena»: 8-23.

15. Shakhovskiy V.I. 2018. Uskorennaya kommunikatsiya kak potrebnost' sovremennogo sotsiuma [Accelerated communication as a need of modern society]. In: Yazykovoe bytie cheloveka i etnosa [Language being of a person and an ethnic group]. Materials of the XV Berezinsky readings, Moscow, may 25, 2018. Eds. V.A. Pishchal'nikova, L.R. Komalova, N.N. Germanova. M., Publ. In-t nauchnoy informatsii po obshchestvennym naukam RAN, 20: 285-293. 
16. Shakhovskiy V.I. 2019. Kategorizatsiya EMOTsIY v leksiko-semanticheskoy sisteme yazyka [Categorization of EMOTIONS in the lexical-semantic system of language]. M., Publ. URSS, 206 p.

17. Shtil'man M.I. 2016. Biomaterialy - vazhnoe napravlenie biomeditsinskikh tekhnologiy [Biomaterials are an important area of biomedical technologies]. Biomedical Yournal of Pirogov University, 5: 4-15.

\section{ИНФОРМАЦИЯ ОБ АВТОРАХ}

Шаховский Виктор Иванович, главный научный сотрудник, доктор филологических наук, профессор, профессор кафедры языкознания Волгоградского государственного социально-педагогического университета, г. Волгоград, Россия

Маджаева Санья Ибрагимовна, доктор филологических наук, доцент, заведующая кафедрой латинского и иностранных языков Астраханского государственного медицинского университета, г. Астрахань, Россия

\section{INFORMATION ABOUT THE AUTHORS}

Victor I. Schakhovsky, chief researcher, Doctor of Philology, Professor, Professor, Department of linguistics, Volgograd state social and pedagogical University, Volgograd, Russia

Sanya I. Madzhaeva, Doctor of Philology, Associate Professor, head of the Department of Latin and foreign languages, Astrakhan state medical University, Astrakhan, Russia 